\title{
PERANCANGAN ULANG PERMAINAN SONLAH UNTUK ANAK USIA 6 SAMPAI 12 TAHUN DI KOTA BANDUNG
}

\author{
Diwan Setiawan ${ }^{1}$, Ahmad Deni Saputra ${ }^{2}$ \\ Prodi S1 Desain Komunikasi Visual, Fakultas Komunikasi dan Desain, \\ Universitas Informatika dan Bisnis Indonesia \\ diwansetiawan@unibi.ac.id¹, ahmaddeni13@gmail.com²
}

\begin{abstract}
Abstrak
Permainan adalah bagian tidak terpisah dalam perkembangan anak. Seiring perkembangan teknologi yang semakin pesat mengakibatkan terjadinya perubahan pola hidup masyarakat perkotaan. Termasuk perubahan pola permainan anak-anak di kota Bandung. Dari permainan tradisonal menjadi digital mengakibatkan permainan tradisional mulai dilupakan oleh anak-anak. Termasuk permainan sonlah mempunyai multi manfaat dalam perkembangan anak-anak, melatih kecerdasan emosional, melatih gerak dan bersosialisasi, dibandingkan permainan digital yang lebih bersifat statis dan individualis. Seperti yang terjadi pada siswa-siswi SDN Cisitu, permainan sonlah mulai jarang dimainkan di halaman rumah ataupun lapangan sekolahan. Tujuan dari penulisan laporan tugas akhir ini adalah untuk merancang ulang permainan sonlah bagi anak-anak berumur 6-12 tahun di kota bandung untuk meningkatkan minat terhadap permainan tradisional khususnya permainan sonlah. Dengan tampilan baru dari sisi tampilan visual, kemasan dan portabel. Media yang dipilih adalah media cetak karena menampilkan sisi fisik,bentuk stafak agar para pemain ikut terlibat sisi emosional, motorik tubuh dan bersosialisasi dalam permain. Metode yang digunakan dalam penulisan laporan tugas akhir ini adalah metode kuantitatif untuk memberikan gambaran dan fakta permainan sonlah di SDN Cisitu. Teknik pengumpulan data dilakukan dengan cara studi lapangan berupa observasi,wawancara dan kuisioner. Proses perancangan ulang permainan sonlah ini didasari dengan teori desain komunikasi visual.
\end{abstract}

\section{Kata kunci: permainan tradisional, Kota Bandung, Desain Komunikasi Visual}

\section{Abstract}

Games are inseparable from child development. Technological advancements have caused lifestyle changes in urban society, including children in Bandung. The shift from traditional games to digital ones caused the former to be forgotten, not excluding sonlah with its multiple benefits in children development; increasing emotional intelligence, physical movement, and social skills, compared to the more static, and individualistic digital games. As what happened in Cisitu Elementary School, sonlah is becoming less played in neighborhood or school field. The goal of this paper is to reinvent the game for children aged six to twelve in Bandung to increase the interest in traditional games especially sonlah, with refreshed visual appearance, packaging, and portability. The game will be printed to expose its physical side and borders so the players would be involved emotionally, motorically, and socially in the game. This paper uses quantitative method to provide data and facts about the game sonlah in Cisitu Elementary School. Data collection is done by field study consisted of observation, interviews, and questionnaires. This reinvention of the game sonlah is based on theory of visual communication and design.

\section{Keywords: traditional games, Bandung, visual communication and design}




\section{PENDAHULUAN}

Perkembangan Teknologi yang semakin pesat, tidak saja berpengaruh kepada pola kehidupan masyarakat secara luas. tetapi juga berdampak kepada permainan anak-anak di perkotaan. Kota Bandung yang masyarakatnya terus berkembang memakai teknologi, merubah pola permainan anak-anak dari tradisional menjadi modern berbasis teknologi. Permainan tradisional perlahan-lahan mulai terlupakan oleh anak-anak. Salah satunya permainan sonlah yang sering dimainkan halaman rumah ataupun dilapangan. Permainan sonlah dimainkan oleh 2 sampai 5 anak-anak, baik anak perempuan maupun laki-laki. Pada permainan ini pemain di tuntut untuk melakukan lompatan dan melempar gacuk tepat pada setapak yang dibuat dengan aturan yang disepakati bersama. Dan pemenangnya ialah yang memiliki setapak paling banyak.

Permainan sonlah mempunyai banyak manfaat bagi anak-anak. Dalam penelitian menyatakan bahwa permainan tradisional mestimulasi anak dalam mengembangkan kerja sama, membantu anak-anak menyesuaikan diri, saling berinteraksi secara positif, dapat mengkondisikan anak dalam mengontrol diri, mengembangkan sikap empati terhadap teman, mentaati aturan, serta menghargai orang lain ${ }^{1}$.

Oleh karena itu penulis melakukan observasi ke beberapa sekolah dasar yang berada di kecamatan Coblong kota Bandung. Salah satunya SDN Cisitu yang berlokasi di J1 Sangkuriang 48. Berdasarkan hasil wawancara penulis, permainan tradisional sudah diperkenalkan melalui kurikulum 2013 dan kegiatan setahun sekali berupa perlombaan permainan tradisional antar sekolah yang diselengarakan oleh diknas kota Bandung2. Media permainan yang digunakan dalam kegiatan ini masih bersifat konvensional. Termasuk media permainan sonlah konvensional terbilang low cost atau tidak perlu membeli peralatan mahal atau benda pendukung yang sulit. Cukup memiliki sebutir kapur kemudian ngacuk, yaitu berupa benda yang ukurannya tidak terlalu besar biasanya berbahan potongan genteng. Meskipun demikian media permainan sonlah konvensional ini memiliki banyak keterbatasan baik dari segi ruang maupun kondisi,cenderung membosankan dari tampilannya.

Dari fakta yang telah didapat, membuktikan bahwa permainan tradisional sudah jarang dimainkan oleh anak-anak dan beralih kepada permainan modern seperti komputer, Tablet dan handphone yang lebih menarik dan menyenangkan yang pada saat ini lebih di sukai anak-anak. Selain lebih menarik cara mengaksesnya pun lebih mudah. Kemajuan teknologi tersebut mengakibatkan ditinggalkannya permainan sonlah yang dulu lebih sering dimainkan oleh anak-anak. Apabila hal ini terus dibiarkan, tidak akan menutup kemungkinan akan musnah karena tidak ada pelestariannya.

Melihat fenomena di atas mengenai keterbatasan media permainan sonlah ini, telah memicu penulis untuk memunculkan inovasi dalam bidang desain grafis berupa media portabel. Media portabel memiliki kemampuan untuk merubah bentuk dan menjadi lebih praktis sehingga dapat mengatasi keterbatasan ruang dan waktu. Penggunaan media yang sesuai dengan kebutuhan dan ramah lingkungan ini menjadi solusinya. Hal ini dapat membuat suatu media dapat dibuat fleksibel dan berpindah-pindah sesuai dengan kebutuhan dan kondisi.

\footnotetext{
${ }^{1}$ Mulyani Nov,Super Asyik Permainan Tradisional Anak Indonesia, Diva Press, Yogyakarta, 2016, hlm.48.

${ }^{2}$ Hasil wawancara Bapak Hasan Guru SDN Cisitu 1, 22 februari 2017, pukul 09.00
} 


\section{KAJIAN PUSTAKA}

Dalam kamus besar Bahasa Indonesia Istilah permainan berasal kata dasar "main" yang mendapat imbuhan "per-an." adalah berbuat sesuatu menyenangkan hati (dengan mengunakan alat atau tidak3. Dengan demikian. "permainan" adalah sesuatu yang dipergunakan untuk bermain , barang atau sesuatu yang di permainkan; perbuatan yang dilakukan dengan tidak sunguh sunguh, biasa saja.

Sedangkan menurut Misbach yang di kutip Novi Mulyani menyimpulkan bahwa : "Permainan adalah situasi bermain yang terkait dengan beberapa aturan dan tujuan tertentu, yang menghasilkan kegiatan dalam bentuk tindakan bertujuan. Dengan demikian, dapat difahami bahwa dalam bermain terdapat aktivitas yang diikat dengan aturan untuk mencapai tujuan tertentu “(2016:46).

Bermain merupakan kebutuhan anak yang paling mendasar saat anak berinteraksi dunia sekitarnya, melalui bermainlah ia lakukan. Bermain menjadi suatu aktifitas yang berlangsung dan spontan dilakukan seorang anak bersama orang lain atau mengunakan bendabenda sekitarnya dengan senang, sukarela dan imajinatif, serta mengunakan perasaan, tangannya, atau seluruh anggota tubuhnya ${ }^{4}$.

\section{METODE PENELITIAN}

Penulis menggunakan metode kualitatif perancangan ini, sebagai pemandu agar fokus penelitian sesuai dengan fakta di lapangan. untuk memberikan gambaran umum tentang latar penelitian dan sebagai bahan perancangan permainan sonlah. Penulis beralasan memilih metode ini untuk mengeksplorsi dan memahami suatu gejala objek penelitian.

Data-data dalam penelitian kualitatif adalah data berupa fenomena atau kejadian sehingga dalam penelitan ini diperlukan teknik-teknik pengumpulan data yang dapat dijelaskan sebagai berikut:
a. Wawancara $\begin{array}{cr}\text { dilakukan } & \text { untuk } \\ \text { data informasi } & \text { yang }\end{array}$

berkaitan dengan objek yang di teliti dalam pengerjaan tugas akhir ini. Penulis melakukan wawancara kepada Bapak Hasanudin guru S.D.N Cisitu 1 Bandung terkait dengan permainan sonlah.

b. Peneliti melakukan observasi lapangan secara partisipasi langsung, agar mendapatkan suatu pandangan yang mendalam tentang keadaan dan situasi yang terjadi di lingkungan, serta kondisi terkini objek diteliti meliputi kejadiankejadian perilaku yang dilihat untuk mendukung penelitian yang sedang dilakukan.

c. Kuesioner merupakan teknik pengumpulan data yang dilakukan dengan cara memberi seperangkat pertanyaan tertulis kepada responden untuk dijawab. Kuesioner digunakan untuk memperoleh informasi dari responden dalam arti laporan tentang pribadi atau hal-hal yang ia ketahui. Kuesioner atau angket di berikan kepada orangtua dan anak-anak untuk mengetahui, mengenal dan manfaat dalam kegiatan sehari-hari terkaik dalam perkembangan anak-anak.

d. Studi dokumen yaitu pengumpulan beberapa data seperti gambar, kumpulan foto atau obyek - obyek yang ditemukan di lapangan selama penelitian dilakukan. Dokumen berupa buku-buku yang diperoleh dari perpustakaan dan jurnal yang didapat dari internet, seperti buku nilai-nilai permainan tradisional pada anak usia sekolah dasar, Pengantar Desain Komunikasi Visual, Psikologi Perkembangan tumbuh kembang anak .

\section{PEMBAHASAN}

\subsection{Strategi Perancangan}

Strategi perancangan berfungsi agar karya desain dapat dibuat dengan baik. Permainan sonlah yang ada saat ini, masih bersifat kovensional hanya memakai "kapur" di uang terbuka, sedangkan seperti kita ketahui bersama ruang terbuka di perkotaan semakin sedikit. 
Sedangkan ruang terbuka yang ada, seperti di taman kota tidak memungkinkan kita untuk mengelar permainan sonlah dengan mengunakan cara kovensional. karena bisa merusak estetika. Oleh karena itu perlu sebuah media permainan sonlah yang lebih menarik secara visual bertematik,bersifat portabel dan mudah dibawa untuk menarik si audiens. Bentuk puzzle sebagai stapak alur permainan sonlah dengan bahan rubber flooring tidak licin dan aman dimainkan anak-anak. Dengan ukuran disesuaikan dengan tampilan bertema kota Bandung.

\subsection{Strategi Komunikasi}

Strategi komunikasi adalah kegiatan langkah-langkah yang diambil untuk mengkomunikasikan desain agar di terima target audience, meliputi strategi visual dan strategi verbal.

\subsubsection{Strategi Visual}

Strategi visual berhubungan desain yang dapat menarik perhatian target audiens. Strategi visual yang digunakan dalam peracangan ulang permainan sonlah antara lain :

1. Warna bergaya blok yang digunakan adalah perpanduan warna cerah dan warna alam.

2. Ilustrasi bersifat Ruang Waktu Datar (RWD) serta Naturalis-PerpektifMoment (NPM).

3. Tipografi dalam perancangan permainan sonlah adalah sans serif dan dekoratif.

\subsubsection{Strategi Verbal}

Strategi verbal berkaitan dengan bahasa, penulis menggunakan kata-kata dan bahasa yang mudah dimengerti dan dipahami oleh anak-anak. Dengan gaya bahasa informatif.

\subsection{Strategi Kreatif}

Strategi kreatif yang dipakai adalah dengan membuat puzzle stapak bergambar harus tersusn. Dipadukan dengan teknik flat desain, yang menanpilkan icon kota bandung.

\subsubsection{Judul dan Tema Permainan}

Judul permainan sonlah adalah " Sonlah kota Bandung”. Permainan ini bertema tentang icon icon di kota Bandung sebagai sarana informasi dan edukasi kepada pemain.

\subsubsection{Bentuk Permainan}

Permainan ini berisi materi edukatif tentang kota Bandung yang tersusun di sebuah gambar dalam bentuk karakter gedung, transpotasi, taman, dan elemen lainnya. Dari setiap stapak permain sonlah ini berbentuk persegi panjang dengan ukuran 1 x 3,5 meter. Karena ukuran latar permain sonlah yang luas,maka anakanak yang menjadi pemain utamanya dengan terjun langsung dalam permainan.

\subsubsection{Gambaran Permainan}

Permainan ini terdiri dalam 1 rangkaian peta besar berukuran 1 x 3,5 meter. Terbagi menjadi 9 stapak wilayah. Dengan ukuran 50 x $50 \mathrm{~cm}$. Disetiap setapak berisikan materi gambar icon dalam bentuk bangunan, transportasi, taman dan jalan. Dari willayah tersebut harus kuasai oleh pemain untuk memenangkan permainan

\subsubsection{Jenis Permainan}

Permain sonlah ini berjenis Area Control/ Area Influence. Mekanisme dimana pemain harus berlomba mendapatkan wilayah tertentu dihitung seberapa banyak pengaruh pemain di area itu, biasanya dimenangkan dengan perhitungan mayoritas.

\subsubsection{Alur Permainan}

Alur permainan sonlah ini terbagi menjadi 9 bagian, yaitu dibedakan dengan nama-nama wilayah kota bandung berbentuk persegi yang masing-masing memiliki batas wilayah yang harus dikuasai. Di mulai dari awal melempar gacuk dan melewati jalan stapak di lalui. Semua sudah di lalui baru melempar gacuk ditempat stapak puncak menandai wilyah. 


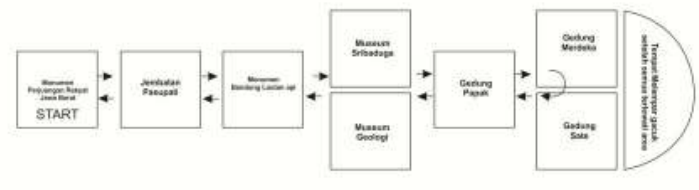

Gambar 4.1

Alur Permainan

Sumber: Olahan Penulis

\subsubsection{Cara Bermain}

Konsep permainan sangat sederhana dimainkan 2 sampai 5 atau lebih. Dimana pemenang permainan sonlah nyaitu yang paling banyak mengusai wilayah. Pertama susun 9 puzzle petak kotak tersebut berurutan. Untuk memulai pemain harus menaati peraturan yang akan di tentukan sebagai berikut :

a) Melakukan hompimpa untuk urutan bermain.

b) Si pemain memilih gacuk yang akan di pakai.

c) Lempar gacuk tersebut ke kotak nomer 1, jika berhasil mulailah melompati ke petak berikutnya dengan 1 kaki

d) Tidak boleh menginjak kotak yang terdapat gacuk kamu didalamnya harus di lewati.

e) Ambil kembali gacuk disaat kembali.

f) Ulangi langkah tadi dikotak nomer 2, dan seterusnya.

g) Giliran selesai atau gagal apabila,gacuk pemain mengenai garis saat dilempar.

h) Kaki pemain menginjak garis saat bermain

i) Gacuk kamu jatuh diluar arena permainan

j) Lanjutkan permainan hingga batu sampai di angka 9

k) Jika sudah selesai hingga angka 9, pemain melempar gacuk dengan menghadap kebelakang
1) Kotak di mana gacuk itu mendarat di jadikan wilayah permain tersebut, dan di tandai dengan sticker bintang.

m) Pemain lain dilarang menginjak wilayah tersebut

n) Lanjutkan permainan hingga seluruh wilayah terisi tanda bintang

o) Pemain yang menang adalah pemain yang banyak memiliki tanda bintang.

\subsubsection{Misi Permainan}

Misi dalam permainan sonlah ini adalah menyelesaikan sebuah rintangan dengan melewati stapak-stapak dan menguasai. Tidak hanya itu, anak-anak juga sembari mengetahui informasi icon kota Bandung dari setiap setafak yang telahmereka lalui.

\subsubsection{Elemen Permainan}

\begin{tabular}{|l|l|l|}
\hline $\begin{array}{l}\text { No } \\
\text { Elemen } \\
\text { permainan } \\
\text { sonlah }\end{array}$ & \multicolumn{1}{|c|}{ Keterangan } \\
\hline 1 & Pemain & $\begin{array}{l}\text { Permainan sonlah di m ainkan 1 } \\
\text { sampai 5 anak atau lebih }\end{array}$ \\
\hline 2 & Tujuan & $\begin{array}{l}\text { Pengenalan icon - icon kota } \\
\text { bandung untuk menganjarkan } \\
\text { sekaligus sebagai pengetahuan } \\
\text { sejarah, informasi agar anak- anak } \\
\text { lebih peduli dengan kota } \\
\text { bandung. untuk belajar } \\
\text { bersosialisali, komunikasi. } \\
\text { Demokrasi, dan taat peraturan. } \\
\text { Melatih motorik fisik }\end{array}$ \\
\hline
\end{tabular}




\begin{tabular}{|l|l|l|}
\hline 3 & Prosedur & $\begin{array}{l}\text { Dengan mnganalisis } \\
\text { permasalahan yang ada dalam } \\
\text { setiap rintangan yang dimainkan } \\
\text { dan melakukan penyelesaian } \\
\text { masalah yang ada. Anak-anak di } \\
\text { ajarkan bagaimana kerja keras } \\
\text { untuk mencapai tujuan dengan } \\
\text { menyelesaikan masalah yang di } \\
\text { lewati. }\end{array}$ \\
\hline 4 & $\begin{array}{l}\text { Aturan } \\
\text { sampaiam permain lebih dari 1 } \\
\text { berurutan harus melewati } \\
\text { rintangan sampai akhir. }\end{array}$ \\
\hline 5 & $\begin{array}{l}\text { Menguasai banyak wilayah } \\
\text { penyelesaikan permasalah di } \\
\text { lewati }\end{array}$ \\
\hline Dayber & $\begin{array}{l}\text { Pemain akan berhadapan } \\
\text { rintangan. Anak-anak diharuskan } \\
\text { menyusuri stapak }\end{array}$ \\
\hline
\end{tabular}

Tabel 4.2

\section{Elemen Dramatis}

\begin{tabular}{|c|l|l|}
\hline No. & $\begin{array}{l}\text { Elemen } \\
\text { permainan } \\
\text { sonlah }\end{array}$ & \multicolumn{1}{|c|}{ Keterangan } \\
\hline 1 & Tantangan & $\begin{array}{l}\text { Permainan akan melewati } \\
\text { berbagai tangtangan dengan } \\
\text { berkompetensi dengan } \\
\text { lawan merebut wilyah. } \\
\text { Dimana pemain tertangtang } \\
\text { untuk mengusai dan } \\
\text { mencontrol wilayah. Dimana } \\
\text { lawan tidak bias melewati. }\end{array}$ \\
\hline
\end{tabular}

\begin{tabular}{|l|l|l|}
\hline 2 & Play & $\begin{array}{l}\text { Dengan menyelesaikan } \\
\text { rintangan dan mengusai } \\
\text { wilayah pemain belajar } \\
\text { tentang kota bandung. } \\
\text { gedung, jembatan sebagai } \\
\text { sumber informasi } \\
\text { pengetahuan dan edukasi. }\end{array}$ \\
\hline 3 & Motif & $\begin{array}{l}\text { Ada 9 stapak yang harus di } \\
\text { kuasai, dengan menguasai } \\
\text { wilayah tersebut. Pemain } \\
\text { akan mengetahui informasi } \\
\text { icon bandung }\end{array}$ \\
\hline
\end{tabular}

\subsubsection{Format dan Ukuran}

Format Ukuran permainan sonlah adalah persegi panjang dengan susunan 10 puzzle stapak $50 \times 50 \mathrm{~cm}$ dan tebal $5 \mathrm{~mm}$. Total ukuran $1 \times$ 3,5 meter. Mengunakan printable flex sebagai transpaper terhadap bahan Rubber Flooring agar tidak licin apabila di pasang lantai.

\subsubsection{Teknik Cetak}

Teknik cetak yang digunakan penulis dalam setafak permain sonlah ini adalah digital print untuk target satuan sebagai dummy dan cetak offset untuk target produksi masal. Digital print dipilih karena cocok untuk kebutuhan mencetak dalam waktu singkat dan kebutuhan sedikit dan penulis menggunakan cetak offset untuk target umum untuk produksi masal agar mengurangi biaya produksi bila dicetak dalam jumlah besar.

\subsection{Konsep Visual}

Dalam perancangan media permainan sonlah, konsep visual yang digunakan flat design. flat Design adalah sebuah style desain dimana fokus pada kesederhanaan (simpel). Konsep Flat Design tidak melibatkan unsur 3D, shadow, gradient, bevel dan lain-lain. Meskipun demikian, Flat Design bukan berarti tanpa efek sama sekali. Flat Design lebih menekankan pada penggunaan warna yang solid, typography, dan elemen elemen sederhana. 


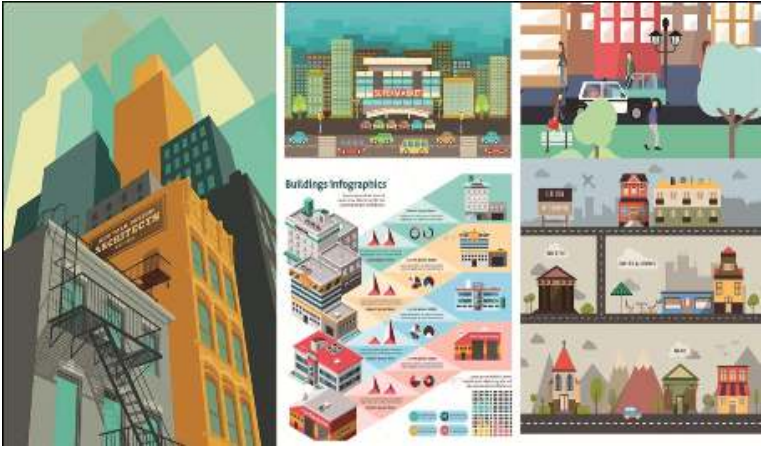

Gambar 4.12

Gaya Flat Design

Sumber: Google 2017

\subsubsection{Layout}

Layout pada setapak pada permainan sonlah ini menggambarkan tata letak komponen visual agar tampak seimbang.

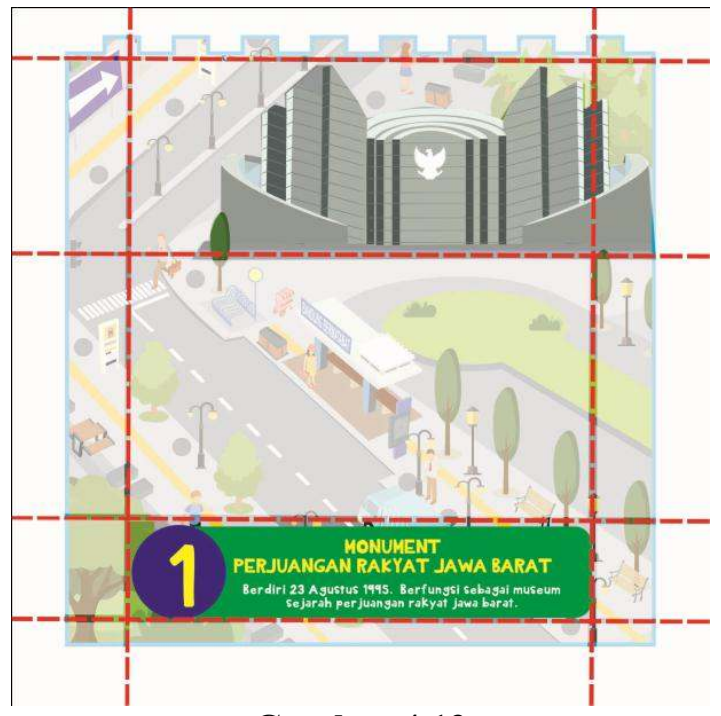

Gambar 4.13

Layout Puzzle Setapak

Sumber: olahan penulis, 2017

\subsubsection{Ilustrasi}

Stapak menggunakan ilustrasi khas anakanak yang bersifat Ruang Waktu Datar (RWD) dan Naturalis-Perspektif-Moment (NPM).

Ilustrasi bergaya design flat yang sederhana dan mengikuti bentuk-bentuk atau gambar flat.

\subsubsection{Logo}

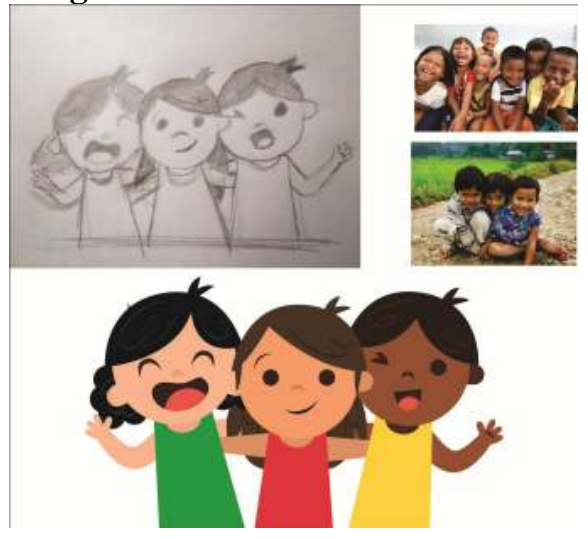

Gambar 4.14

Sektsa dan Ilustrasi logo

Sumber: olahan penulis, 2017

Logo mengunakan 3 karakter anak ketawa dan tersenyum saling berpegangan, untuk mewakili persahabatan di padukan dengan warna yang ceria, dengan warna kulit berbeda untuk mengambarkan kecerian, kesenangan dan kebersamaan. Logo ini untuk mendukung branding dalam kemasan produk.

\section{PERANCANGAN}

Perancangan menurut Kamus Besar Bahasa Indonesia asal kata rancang artinya bangunan desain, di beri imbuhan "pe-an" menjadi perancangan, yang mengandung arti "proses, cara, pembuatan merancang7. Definisi perancangan menurut bin Ladjamudin adalah "Perancangan adalah tahapan perancangan (design) memiliki tujuan untuk mendesain sistem baru yang dapat menyelesaikan masalah-masalah yang dihadapi perusahaan yang diperoleh dari pemilihan alternative sistem yang terbaik" (2005:39).

Sedangan definisi menurut Kusrini dkk "perancangan adalah proses pengembangan spesifikasi sistem baru berdasarkan hasil rekomendasi analisis sistem"8. Berdasarkan pengertian di atas penulis dapat menyimpulkan bahwa perancangan adalah suatu proses 
pembuatan media atau karya dari analisis, riset untuk mengembangkan dan mendesain sistem yang baru. Sesuai dengan tujuan yang akan di terapkan.

\subsubsection{Ikon Kota Bandung}

Ikon Bandung mengambil gedung-gedung bersejarah, gedung pemerintah dan bangunan yang menjadi ciri khas kota Bandung yang di kenal oleh masyarakat.

\section{a. Monument Perjuangan Rakyat Jawa Barat.}

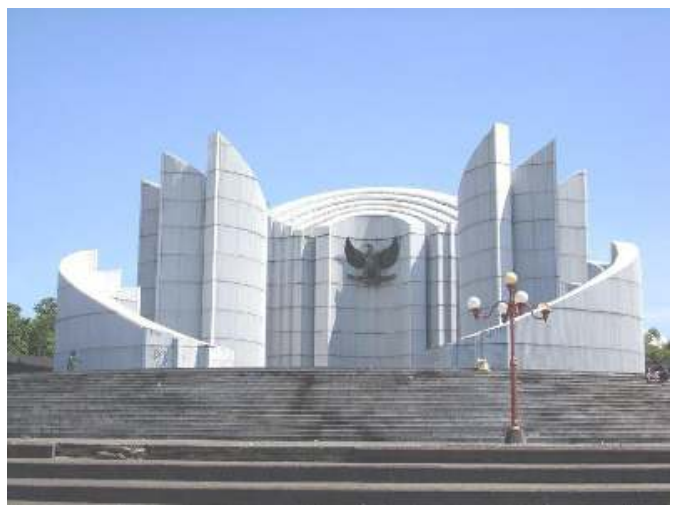

Gambar 4.15

Monument Perjuanga Rakyat Jawa Barat Sumber: Dokumentasi Google, 2017

Monumen Perjuangan Rakyat Jawa Barat terletak di Jalan Dipati Ukur No. 48, Kota Bandung. Lokasinya berhadapan dengan Gedung Sate dan di depan Kampus Universitas Padjadjaran (Unpad), Kota Bandung. Monumen berdiri di atas tanah seluas $\pm 72.040 \mathrm{~m}^{2}$ dan luas bangunan $\pm 2.143 \mathrm{~m}^{2}$. serta model bangunannya, berbentuk bambu runcing yang dipadukan dengan gaya arsitektur modern. Monumen diresmikan penggunaanya oleh Gubernur Jawa Barat, R. Nuriana pada tanggal 23 Agustus 1995. Ilustrasi monument Perjuangn Rakyat Jawa Barat yang penulis buat dalam setapak puzzle adalah sebagai berikut.

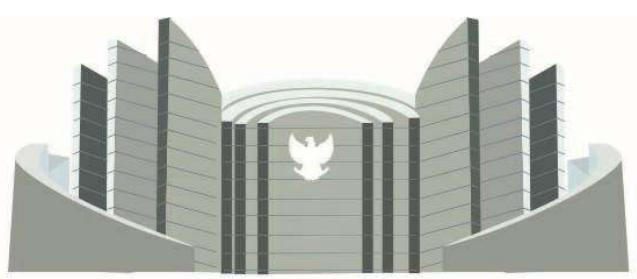

Gambar 4.16

Ilustrasi Monument Perjuangan Rakyat Jawa Barat

Sumber: Olahan Penulis, 2017

b. Jembatan Pasupati

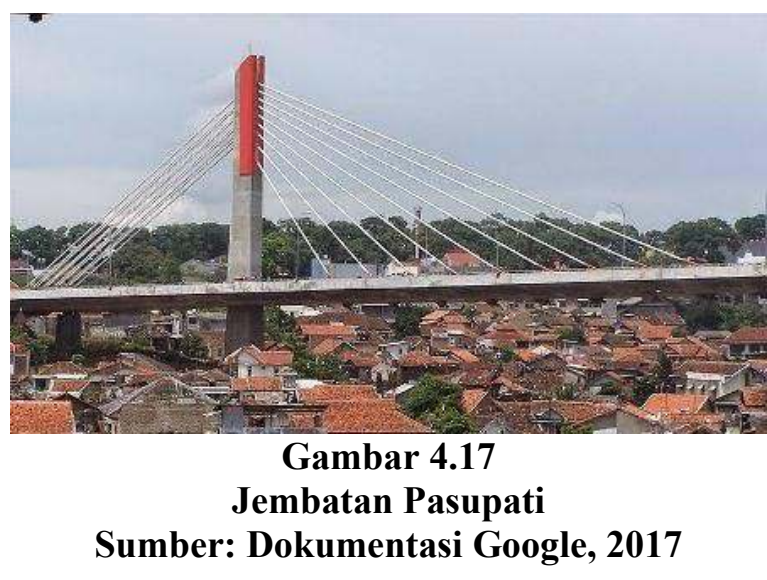

Jembatan Pasupati atau Jalan Layang Pasupati adalah sebuah jembatan yang menghubungkan bagian utara dan timur Kota Bandung melewati lembah Cikapundung. Panjangnya 2,8 km dan lebarnya 30-60 m. Sebagian jalan itu dibangun di atas jalan Pasteur, adalah jalan lama dengan pohon palm raja disebelah kanan dan kirinya yang menjadi ciri kota Bandung. Jalan Layang Pasupati juga menjadi salah satu ikon Kota Bandung. Ilustrasi Jembatan Pasupati yang penulis buat dalam setapak puzzle adalah sebagai berikut.

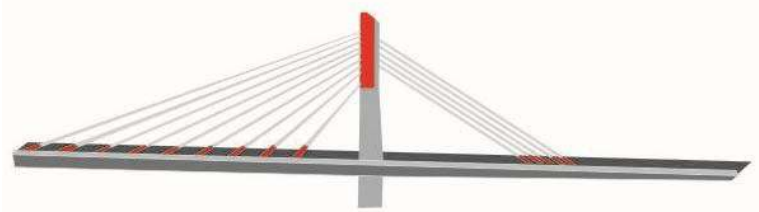

Gambar 4.18

Ilustasi Jembatan Pasupati Sumber: Olahan Penulis, 2017 
c. Monument Bandung Lautan Api.

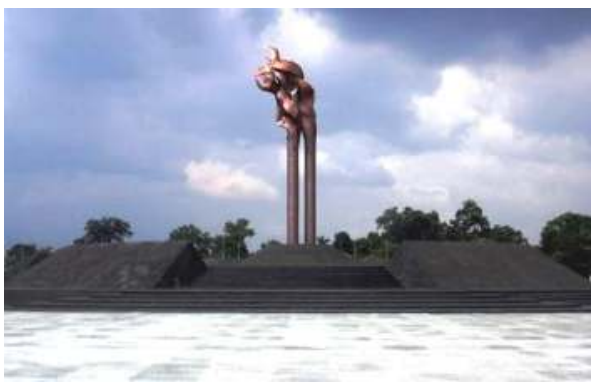

Gambar 4.19

Monument Bandung Lautan Api Sumber: Dokumentasi Google, 2017

Monumen Bandung Lautan Api adalah sebuah perwujudan bentuk penghargaan terhadap para pejuang kemerdekaan Republik Indonesia. Pada saat itu, dalam waktu tujuh jam, sekitar $200.000 \quad$ penduduk Bandung membakar rumah mereka, meninggalkan kota menuju pegunungan di daerah selatan Bandung. Merupakan ikon kota Bandung yang belokasi di tengah kota. Ilustrasi Monument Bandung Lautan Api yang penulis buat dalam setapak puzzle adalah sebagai berikut.

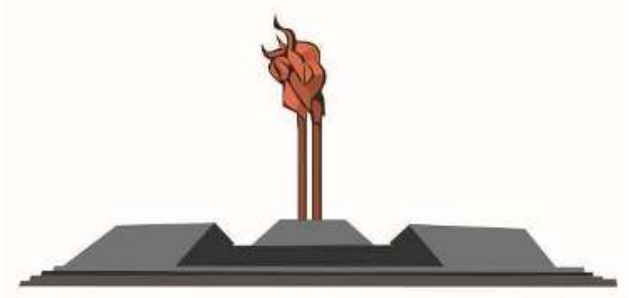

Gambar 4.20

Ilustrasi Bandung Lautan Api Sumber: Olahan Penulis, 2017 d. Museum Sri Baduga

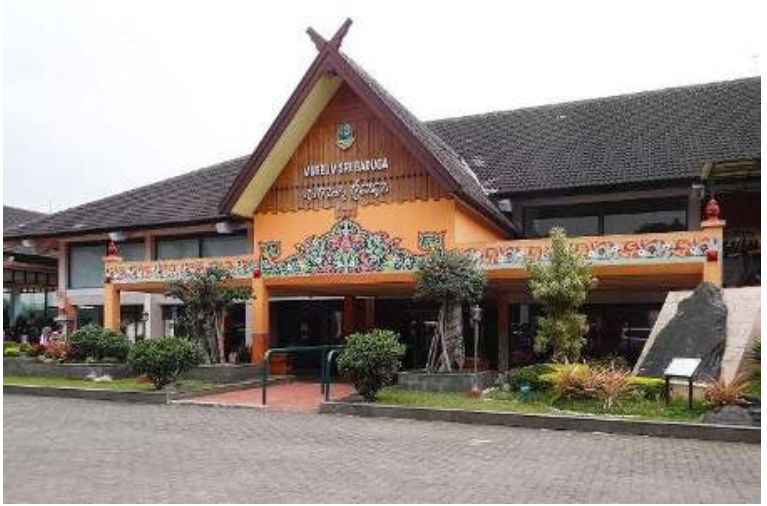

Gambar 4.21

Museum Sri Baduga

Sumber: Dokumentasi Google, 2017

Museum Sri Baduga salah satu tempat wisata bersejarah di Bandung yang populer dengan nama Museum Sri Baduga Bandung, adalah bukti kecintaan warga jawa barat keturunan suku sunda khususnya yang mengabadikan sebuah bangunan bergaya suhunan panjang dan panggung khas Jawa Barat dengan segala benda -benda pusaka sebagai harta tidak ternilai yang ada di dalamnya. Penulis mengilustrasikan flat sebagai ikon di setapak.

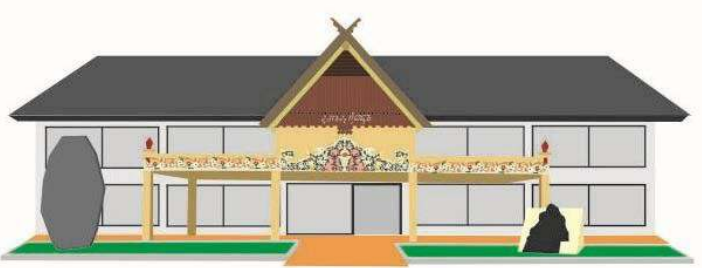

Gambar 4.22

Ilustrasi Museum Sri Paduka Sumber: Olahan Penulis, 2017 
e. Museum Geologi

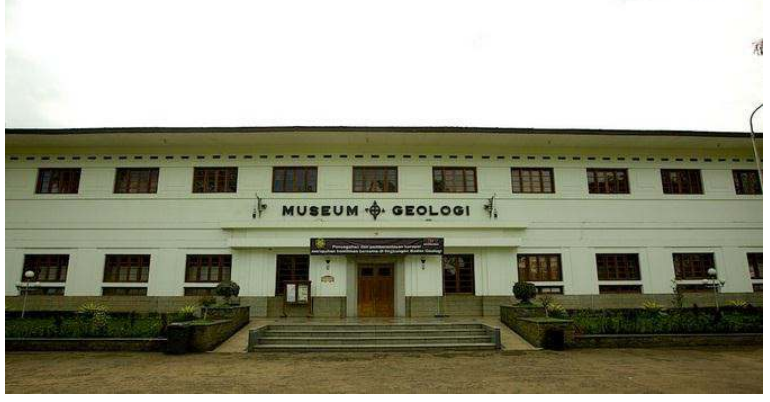

Gambar 4.23

Museum Geologi

Sumber: Dokumentasi Google, 2017

Museun Geologi Bandung adalah sebuah museum yang sudah menjadi bangunan bersejarah di kota Bandung, sehingga menarik minat banyak wisatawan. Museum Geologi Bandung juga sering kali menjadi tempat tujuan study tour sekolah-sekolah yang berlokasi di kota Bandung. Penulis mengilustrasikan flat sebagai ikon di setapak.

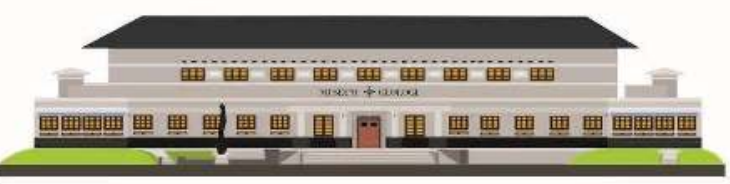

Gambar 4.24

Ilustrasi Museum Geologi Sumber: Olahan Penulis, 2017

f. Gedung Papak

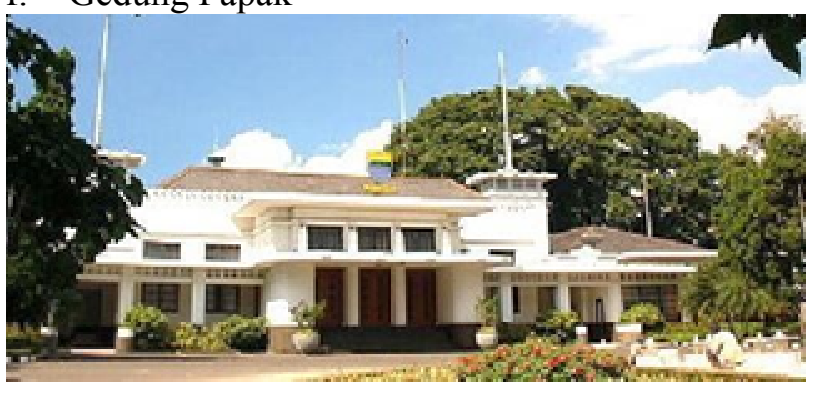

Gambar 4.25

Gedung Papak

Sumber: Dokumentasi Google, 2017
Gedung balai kota yang dirancang oleh arsitek EH de Roo. Pendirian balaikota ini terkait dengan status Bandung sebagai kota praja sejak tahun 1906. . Ia merancang gedung baru ini dengan gaya "art deco" sehingga berkesan lebih modern daripada gedung lama. Bentuk atapnya yang tampak datar menyebabkan gedung ini pun disebut Gedung Papak. Gedung papak menjadi ikon kota bandung yang sering dikunjungi masyarakat Bandung. Penulis mengilustrasikan flat sebagai ikon di setapak.

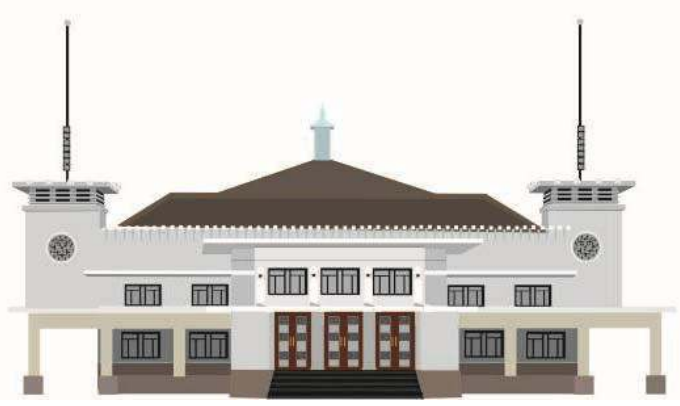

Gambar 4.26

Ilustrasi Gedung Papak

Sumber: Olahan Penulis, 2017

g. Gedung Merdeka

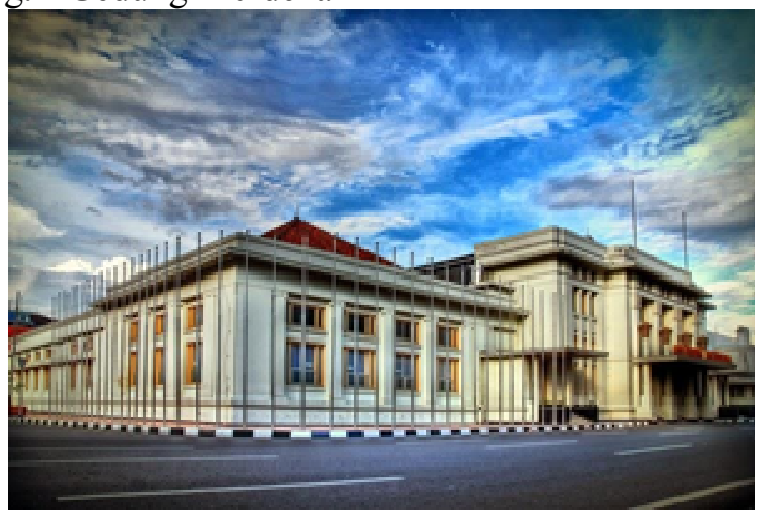

Gambar 4.27

Gedung Merdeka

Sumber: Dokumentasi Google, 2017 
Gedung Merdeka di jalan Asia-Afrika, Bandung, Indonesia, adalah gedung bersejarah yang pernah digunakan sebagai tempat Konferensi Tingkat Tinggi Asia-Afrika tahun 1955. Kini gedung ini digunakan sebagai museum yang memamerkan berbagai benda koleksi dan foto Konferensi Asia-Afrika yang merupakan cikal bakal Gerakan Non-Blok pertama yang pernah digelar disini tahun 1955 . Penulis mengilustrasikan flat sebagai ikon di setapak.

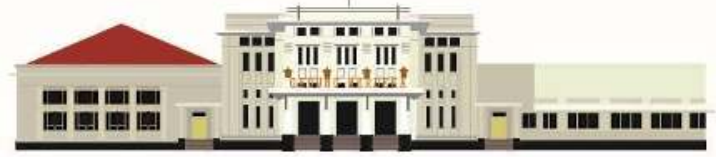

Gambar 4.28

Ilustrasi Gedung Merdeka Sumber: Olahan Penulis, 2017

h. Gedung Sate

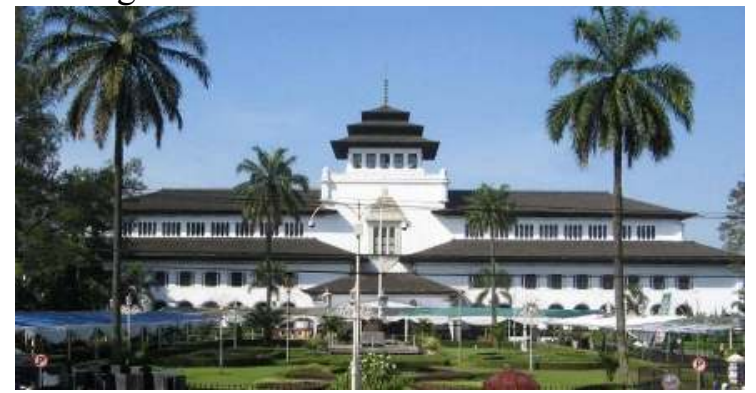

Gambar 4.29

Gedung Sate

Sumber: Dokumentasi Google, 2017

Gedung Sate, dengan ciri khasnya berupa ornamen tusuk sate pada menara sentralnya, telah lama menjadi penanda atau markah tanah Kota Bandung yang tidak saja dikenal masyarakat di Jawa Barat, namun juga seluruh Indonesia bahkan model bangunan itu dijadikan pertanda bagi beberapa bangunan dan tanda-tanda kota di Jawa Barat., gedung masih berdiri kokoh namun anggun dan kini berfungsi

sebagai gedung pusat pemerintahan Propingsi Jawa Barat. Penulis mengilustrasikan flat sebagai ikon di setapak.

\subsubsection{Elemen-Elemen Kota Bandung}

Dalam perancangan permain sonlah penulis mengunakan elemen - elemen identik yang ada di kota bandung sebagai ilustrasi dalam konsep media utama

\subsubsection{Tipografi}

Pemilihan huruf yang baik harus mengarah pada tingkat keterbacaan dan kemenarikan yang baik, selain itu bentuk tipografi juga harus menggambarkan karakter dari pesan yang disampaikan. Tipografi yang digunakan dalam permainan sonlah ini adalah tipografi sans serif atau tipografi tanpa sirip/serif dan font dekoratif dengan font besar agar mudah dibaca anak-anak. Tipografi-tipografi tersebut antara lain sebagai berikut:

a. "Gill Sans Ultra Bold" Alasan penulis menggunakan tipografi tersebut karena jenis tipografi tersebut sangat sesuai dengan target audiens. Dimana font tersebut keterbacaan jelas.bagi anak .

\section{Gill Sans Ultra Bold}

\section{A B E DEF G H I KLM P P R ST U PWXZ a bed ef g h I j k I m • p q rstup wXz 1234567890}

\section{Gambar 4.31 \\ Font Gill Sans Ultra Bold Sumber: Outfonts.com, 2017}

b. " KBPlanet Earth " alasan penulis yaitu untuk menambahkan kesan natural dan fleksibel . Dan memberikan pendekatan dan menarik perhatian anak. Dimana huruf ini itu dan mudah di cerna. 


\section{KBPlanet Earth}

\section{ABDCEF GHIJKLMOPQRSTUPWXZ abcdefghljkImopqrstupwXz 1234567890}

\section{Gambar 4.32 \\ Font KBPlanet Earth Sumber: Outfonts.com, 2017}

\subsubsection{Warna}

Warna merupakan unsur penting dalam pembuatan desain. Dengan warna dapat menampilkan identitas atau citra yang di inginkan. Baik dalam menyampaikan pesan atau membedakan sifat secara jelas. Dalam pemilihan warna desain ulang permainan sonlah ini menggunakan warna dengan nuansa yang cerah,ceria dengan unsur - unsur warna nuansa kota Bandung.

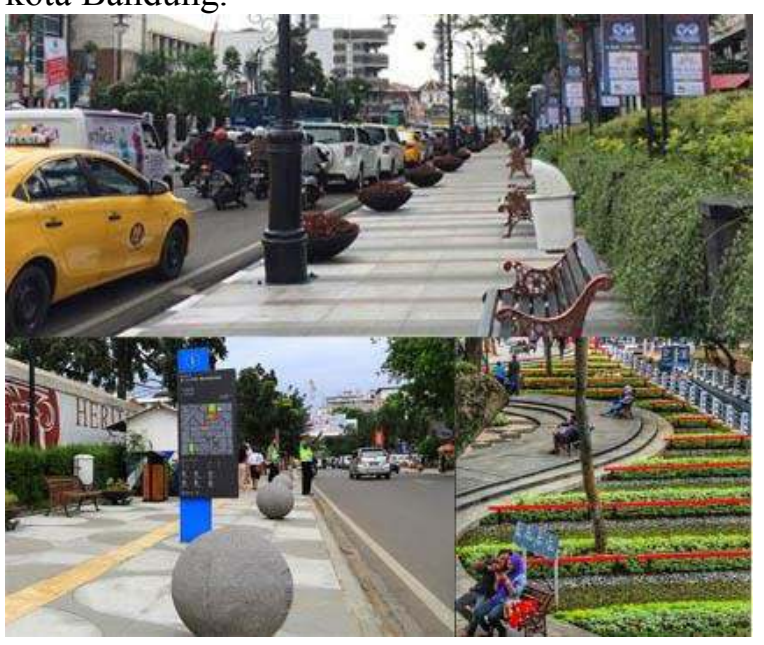

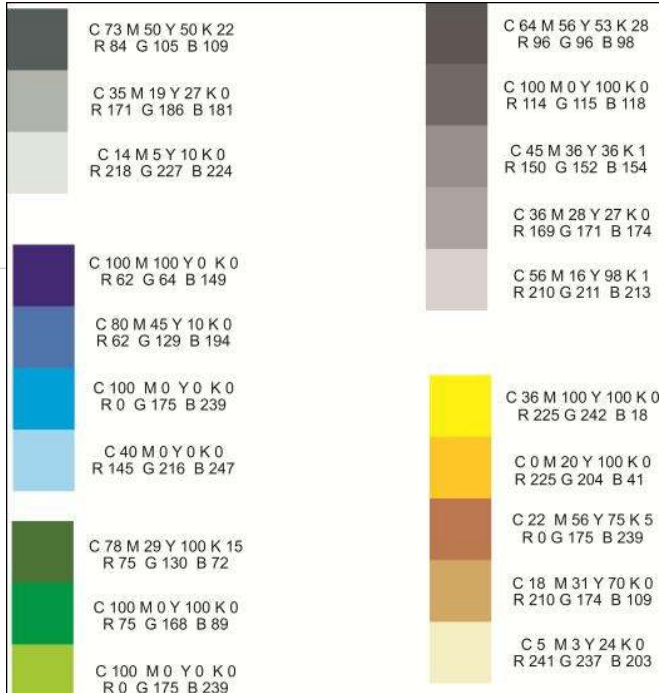

Gambar 4.33

Palet Warna

Sumber: Olahan Penulis, 2017

\subsection{Impletasi Media}

\subsubsection{Media Utama}

Media utama permainan sonlah dibuat berupa papan setapak tersusun 10 puzzle disusun berurutan. Penulis mengunakan stapak bulan merupakan hasil angket yang di bagikan kepada anak-anak. Setiap wilayah stafak mempunyai tema ikon tersendiri yang saling berhubungan dengan kota Bandung. 


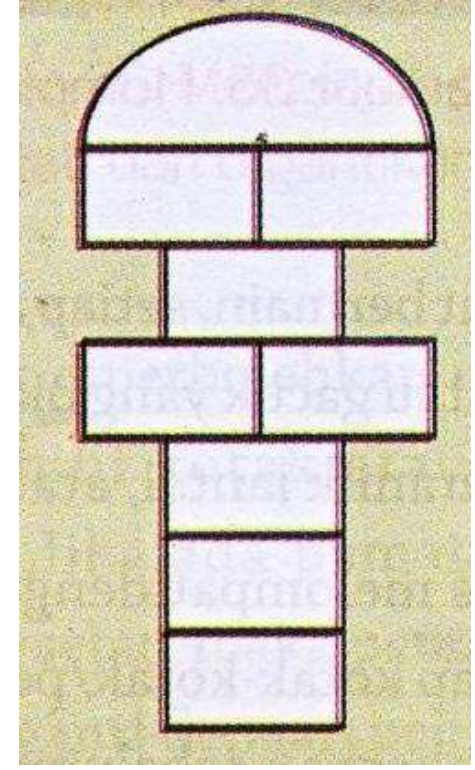

Gambar 4.34

Setapak Bulan

Sumber: Olahan Penulis, 2017

\section{Setapak 1}

Dalam konsep desain setapak 1 penulis menampilkan ikon monument perjuangan rakyat jawa barat. Di padukan dengan trotoar jalan dago, halte bis, dengan di padukan elemen elemen tempat sampah, tempat duduk, lampulampu jalan menjadi komposisi mengambarkan perpaduan taman monument perjuangan dan $\mathrm{J} 1$ Dago merupakan ikon masyarakat kota bandung. Konsep layout balance menempatkan font center di bawah ikon monument jawa barat sebagai informasi ke audiens.

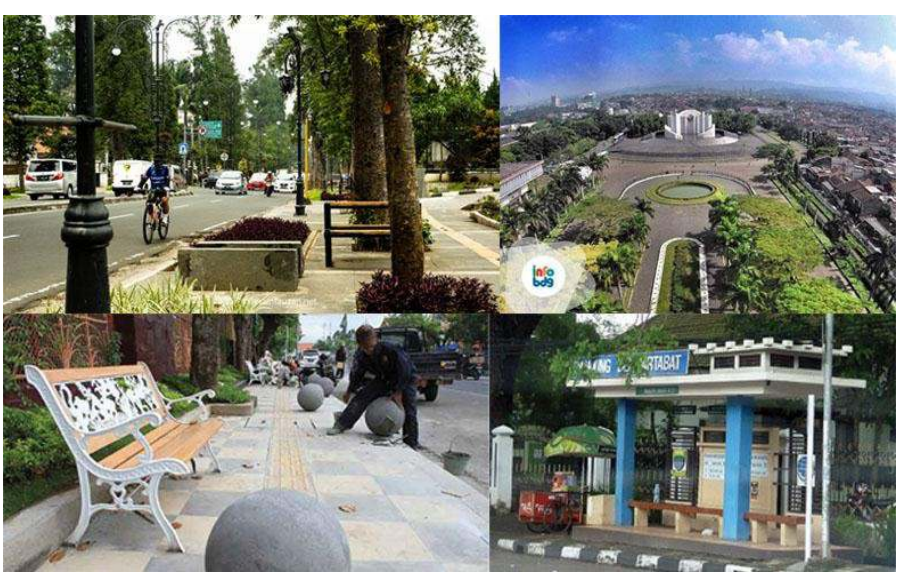

Gambar 4.35

Konsep Visual Setapak 1

Sumber: Google, 2017

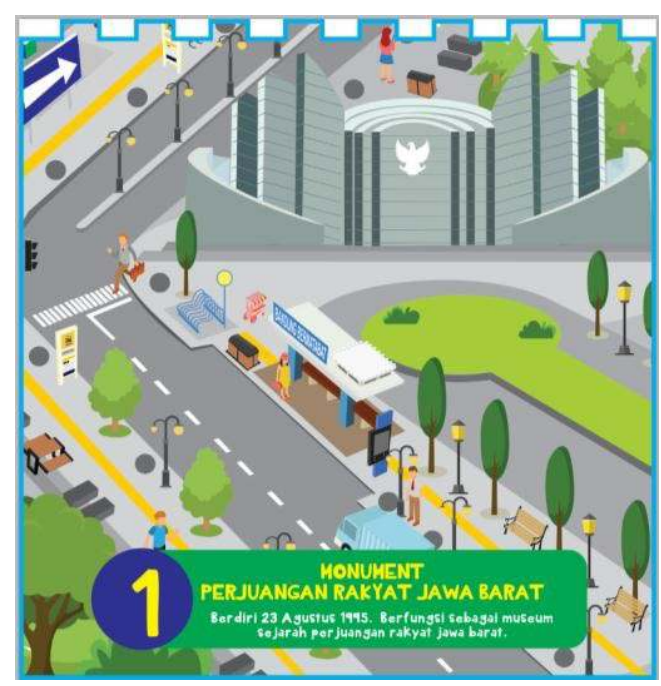

Gambar 4.36

Setapak 1 Ikon Monument Perjuangan Jawa barat

Sumber: Olahan Penulis, 2017

\section{Setapak 2}

Dalam konsep Setapak 2 ikon jembatan pasupati dengan landmark gasibu, taman film dan taman dago sebagai elemen yang mendukung komposisi lantar ikon utama yang di tampilkan, denga suasa aktivitas kota. Penampilan font sebagai informasi balance vertical dengan ikon utama. 

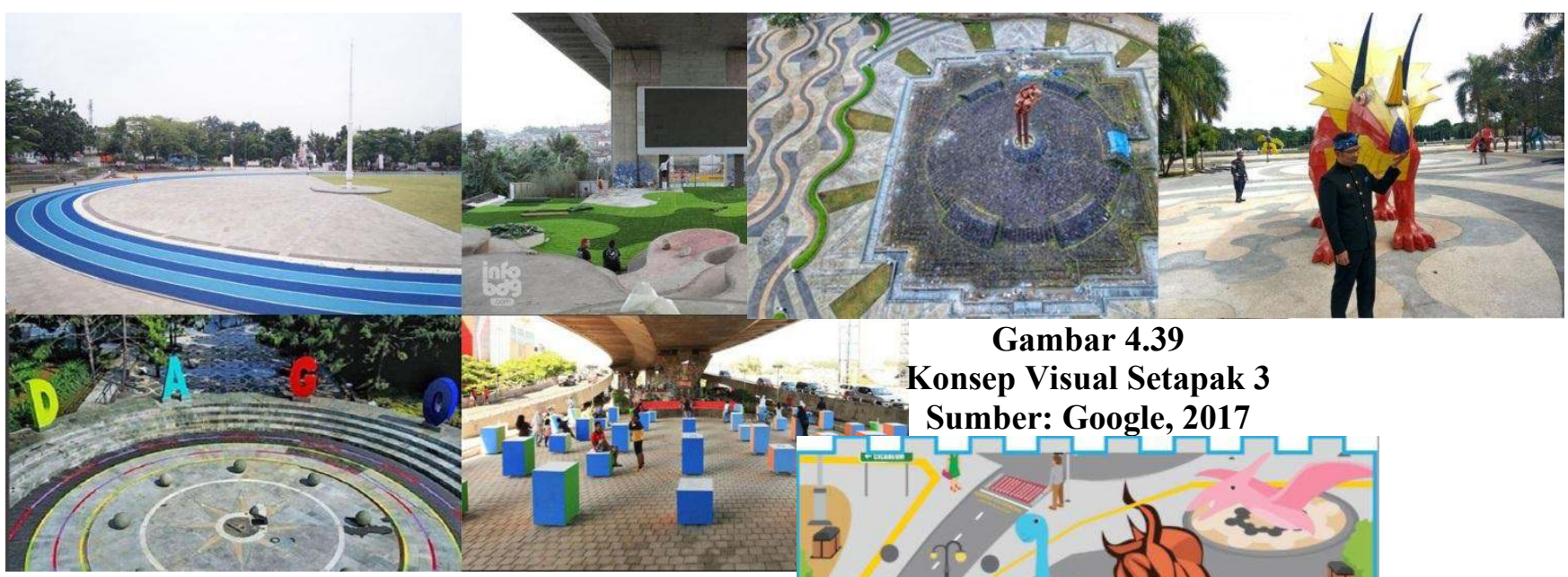

Gambar 4.39

Konsep Visual Setapak 3

Gambar 4.37

Konsep Visual Setapak 2

Sumber: Google, 2017

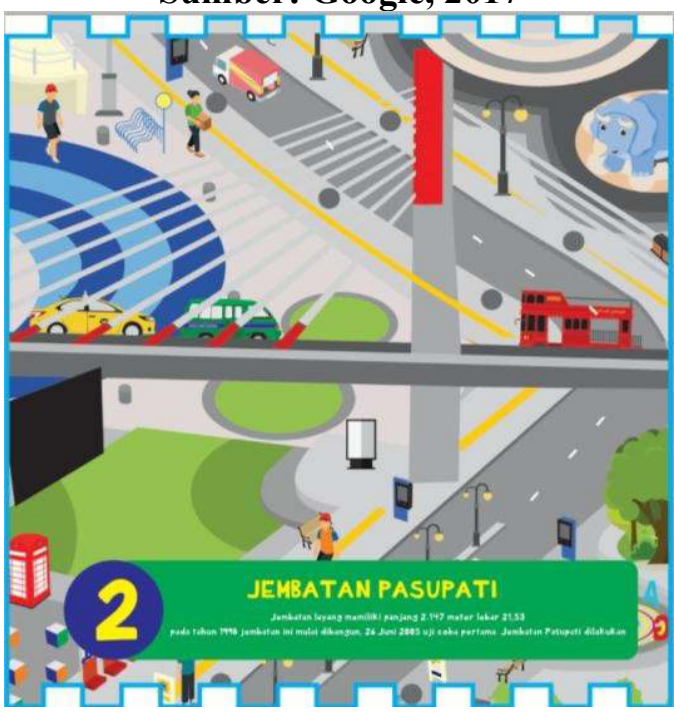

Gambar 4.38

Setapak 2 Ikon Jembatan Pasupati Sumber: Olahan Penulis, 2017

\section{Setapak 3}

Konsep Setapak 3 permainan sonlah ini menampilakan ikon monument bandung lautan api. Dengan lantar background taman dinosaraus sebagai pendukung ikon utama. Penampilan teks sebagai informasi, layout balance vertical dengan ikon utama.

\section{Sumber: Google, 2017}

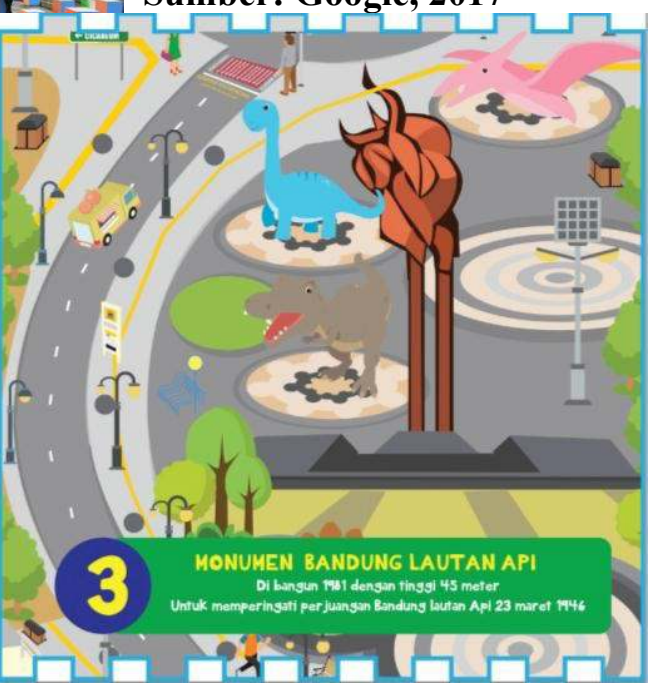

Gambar 4.40

Setapak 3 Ikon Monument Bandung Lautan Api

Sumber: Olahan Penulis, 2017

\section{Setapak 4}

Konsep Setapak 4 menampilkan ikon utama museum Sri Baduga dengan latar background taman cikapundung sebagai pendukung komposisi ikon utama. layout font balance vertical dengan ikon utama. 


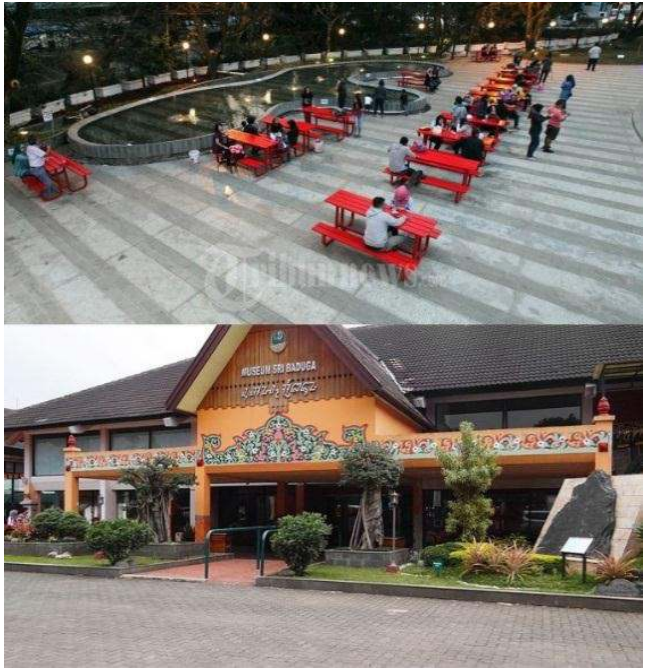

Gambar 4.41

Konsep Visual Setapak 4

Sumber: Google, 2017

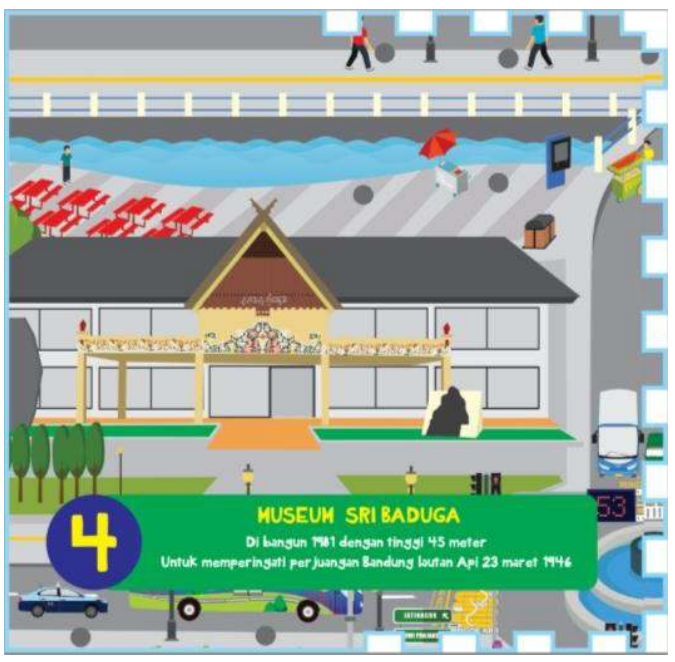

Gambar 4.42

Setapak 4 Ikon Museum Sri Baduga Sumber: Olahan Penulis, 2017

\section{Setapak 5}

Konsep Setapak 5 menampilkan ikon utama museum geologi, dengan latar background taman cikapundung sebagai kesatuan dalam komposisi desain dengan ikon utama. layout font balance vertical dengan ikon utama.

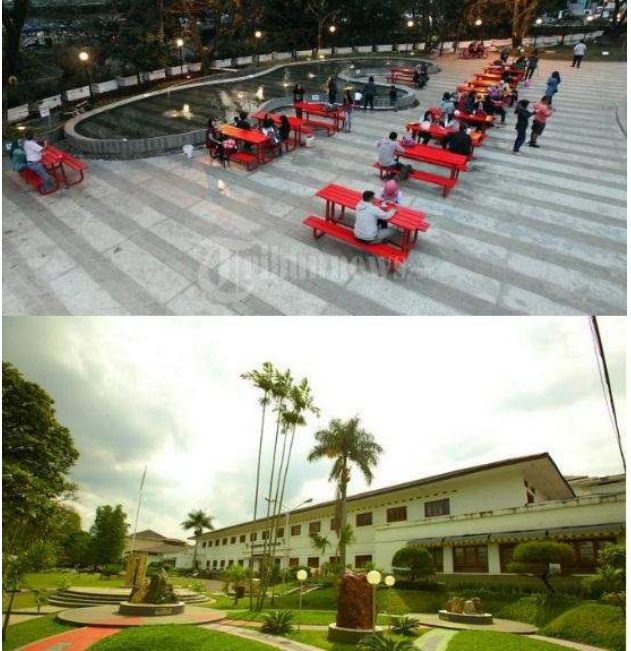

Gambar 4.43

Konsep Visual Setapak 5

Sumber: Google, 2017

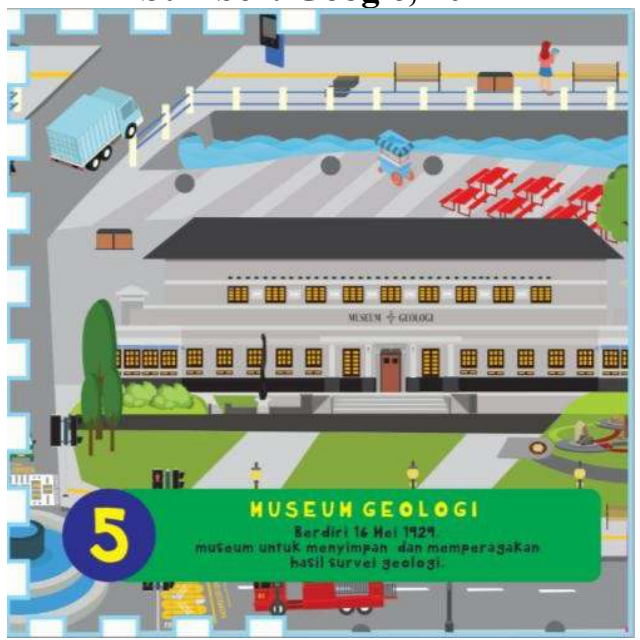

Gambar 4.44

Setapak 5 Ikon Museum Geologi Sumber: Olahan Penulis, 2017

\section{Stapak 6}

Konsep Setapak 6 menampilkan ikon utama gedung Papak dengan latar background taman balai kota bandung dan Taman Sejarah sebagai pendukung ikon utama dalam komposisi desain. layout font balance vertical dengan ikon utama. 


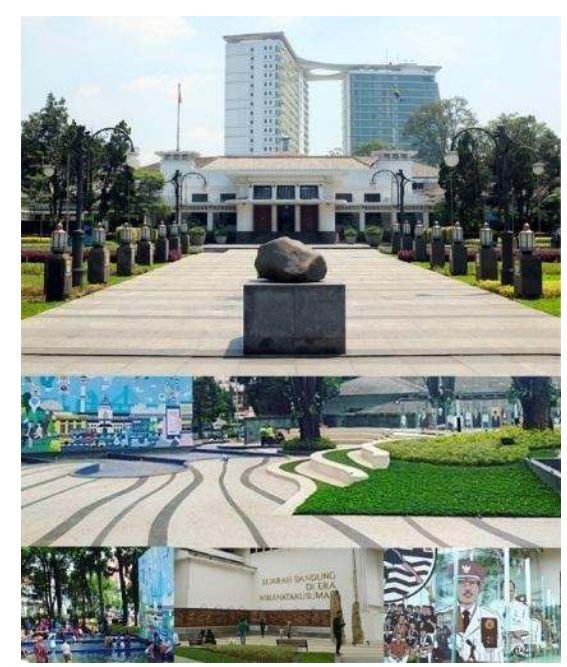

Gambar 4.45

Konsep Visual Setapak 6 Sumber: Google, 2017

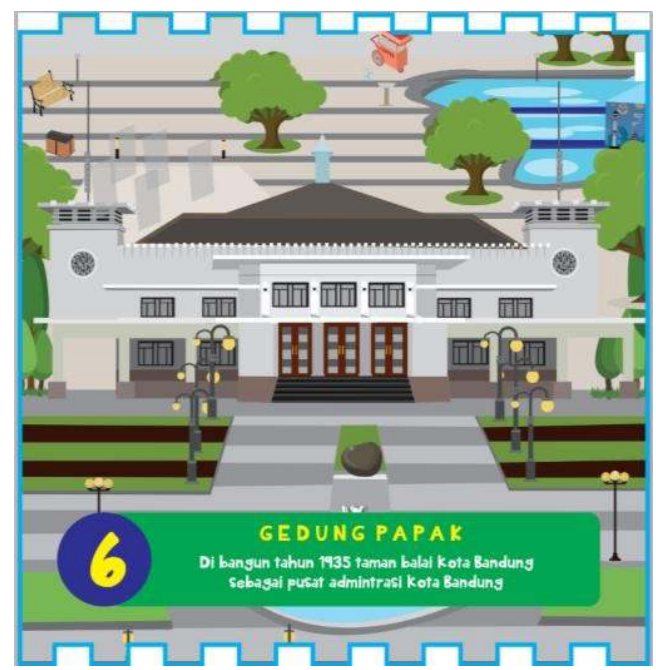

Gambar 4.46

Setapak 6 Ikon Gedung Papak

Sumber: Olahan Penulis, 2017

\section{Setapak 7}

Konsep Setapak 7 menampilkan ikon utama Gedung Merdeka dengan latar background gedung gedung sebagai pendukung ikon utama dalam komposisi desain. layout font balance vertical dengan ikon utama.

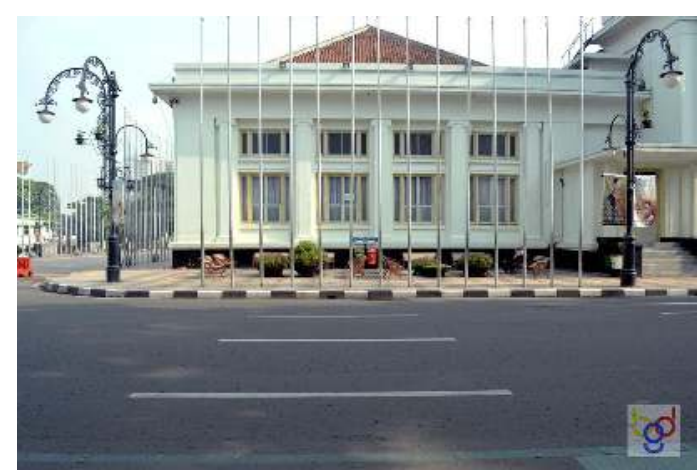

Gambar 4.47

Konsep Visual Setapak 7

Sumber: Google, 2017

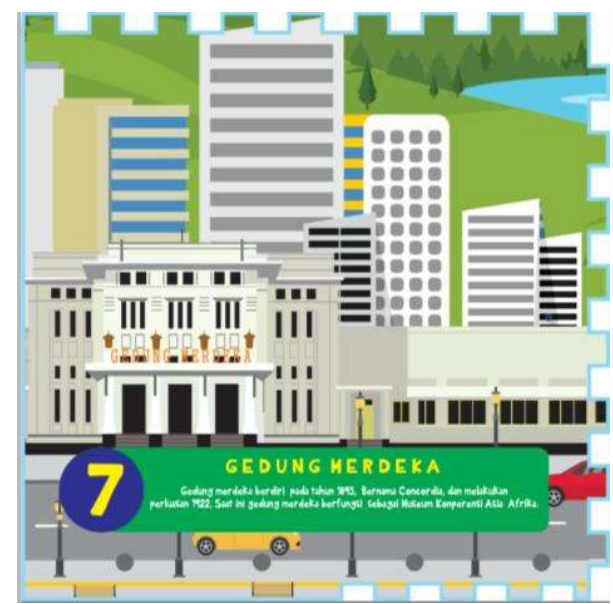

Gambar 4.48

Setapak 7 Ikon Gedung Merdeka Sumber: Olahan Penulis, 2017

\section{Setapak 8}

Konsep Setapak 8 menampilkan ikon utama Gedung Sate dengan latar background danau situ lembang,taman halaman gedung sate sebagai pendukung ikon utama dalam komposisi desain. layout font balance vertical dengan ikon utama. 


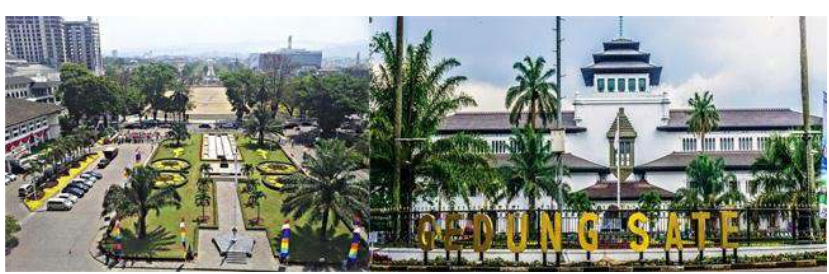

Gambar 4.49

Konsep Visual Setapak 8

Sumber: Google, 2017

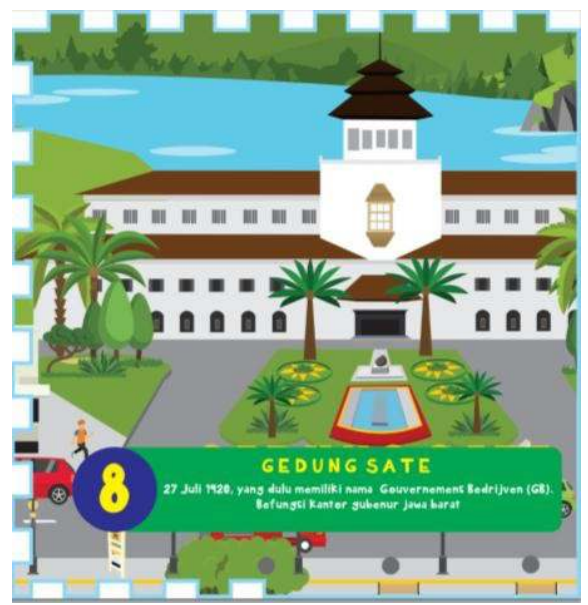

Gambar 4.50

Setapak 8 Ikon Gedung Sate Sumber: Olahan Penulis, 2017

\section{Setapak 9}

Konsep Setapak 9 menampilkan pemandangan gunung Tangkuban perahu yang terkesan sebagai tempat peristirahtan hijau dan sejuk hawa pengunungan.

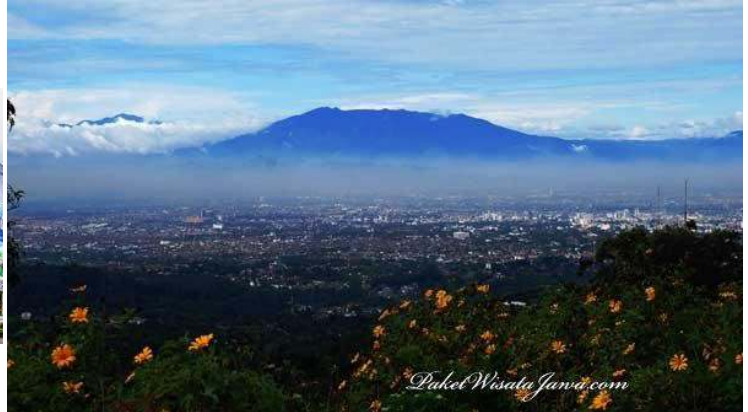

Gambar 4.51

Konsep Visual setapak 9

Sumber: Google, 2017

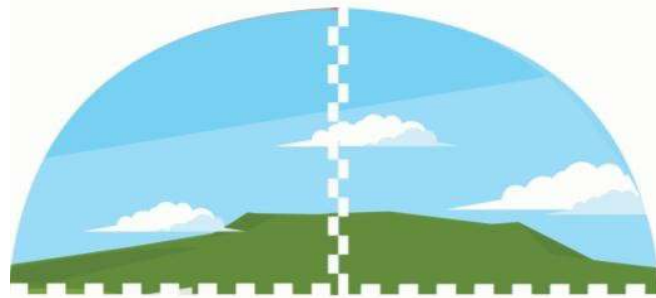

Gambar 4.52

Setapak 9 Gunung Tangkupan Perahu Sumber: Olahan Penulis, 2017

Konsep stapak permainan sonlah menjadi kesatuan dalam memainkan. Setapak tersebut yang harus di perebutkan stafak yang di lalui oleh pemain.

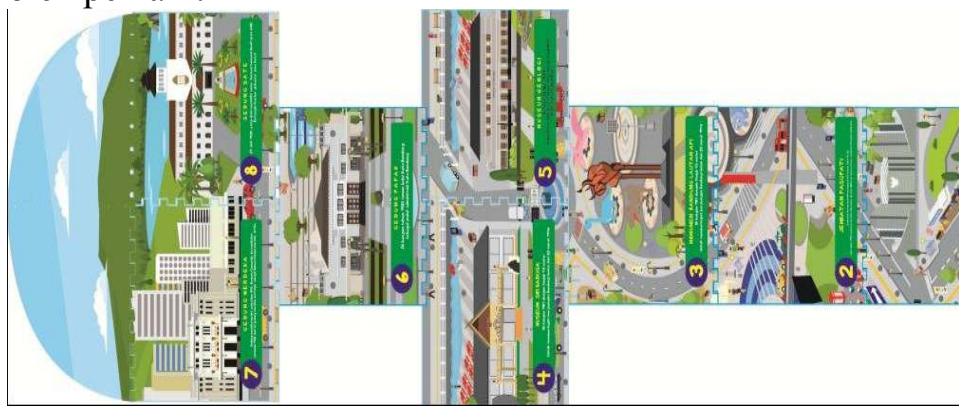

Gambar 4.53

Konsep Media Utama

Sumber: Olahan Penulis, 2017 


\subsubsection{Media Pendukung}

Media pendukung yang digunakan merupakan media tambahan untuk mendampingi media utama agar dapat diaplikasikan dalam permainan sebagai informasi . Ada beberapa media pendukung diantaranya:

a. Gacuk
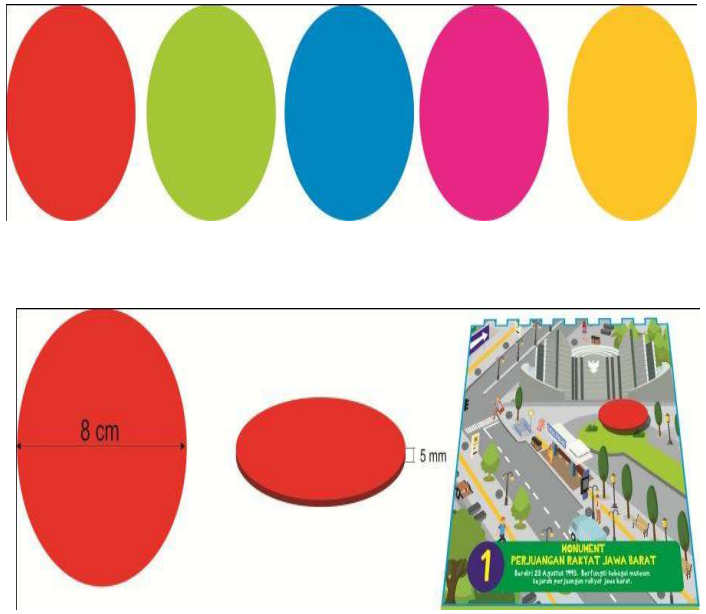

Gambar 4.54

Gacuk

Sumber: Olahan Penulis, 2017

Alat sebagai pelempar untuk menandai petak yang akan di lompati oleh pemain. Setiap pemain mempunyai gacuk pilihan nya. Untuk permainan sonlah tradisional mengunkan pecahan getting, keramik, atau batu berbentuk datar. Penulis merancang gacuk yang efesien dengan warna warna cerah, setiap pemain memiliki warna sendiri sebagai petanda.

\section{b. Buku Panduan}

Buku berukuran A4 bahan art paper 210 g. berisi tentang aturan main dan agar si pemain mengetahui aturan permainan tersebut.

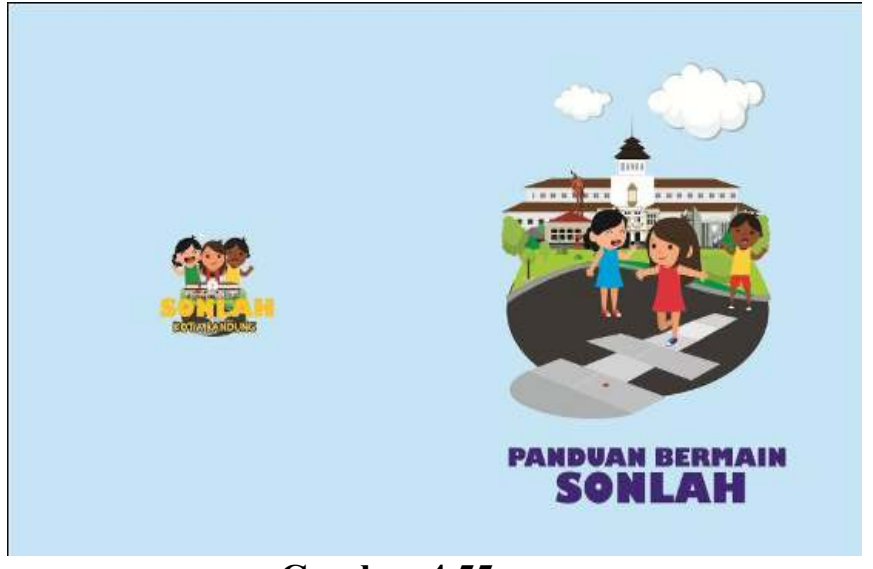

Gambar 4.55

Cover Depan Belakakang Buku Panduan Sumber: Olahan Penulis, 2017
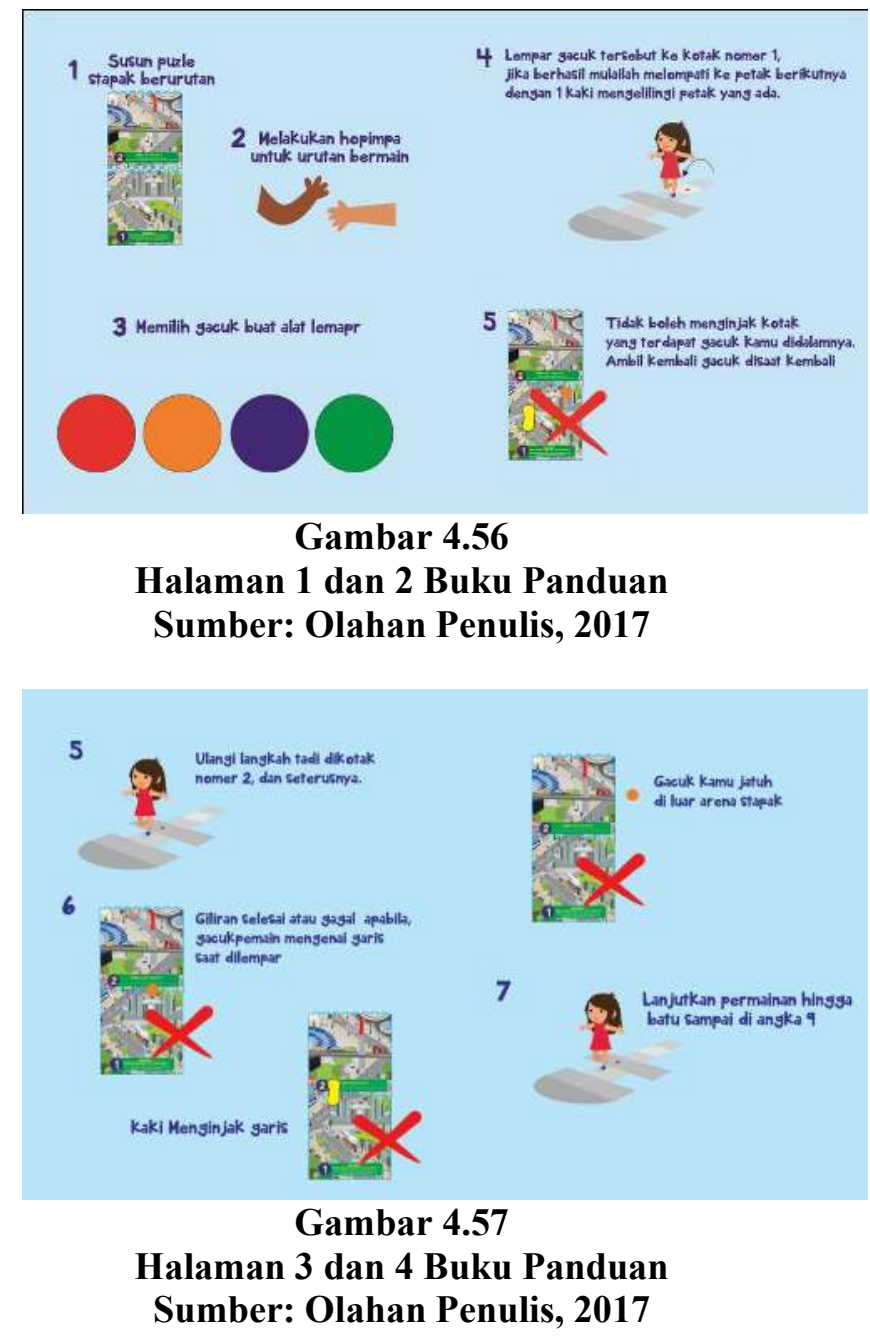


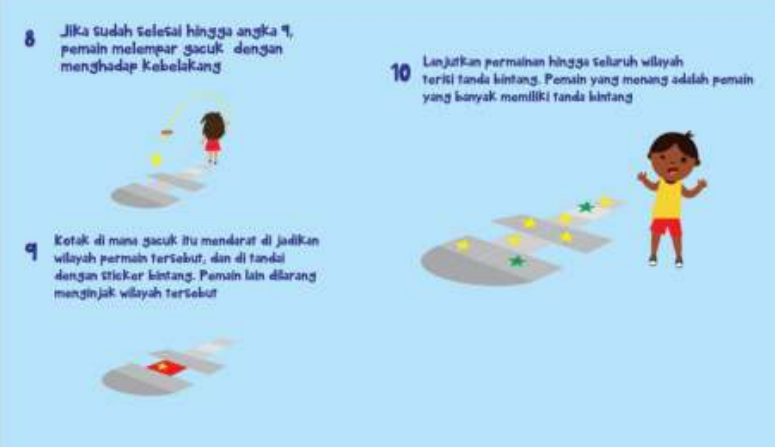

Gambar 4.58

Halaman 5 dan 6 Buku Panduan

Sumber: Olahan Penulis, 2017

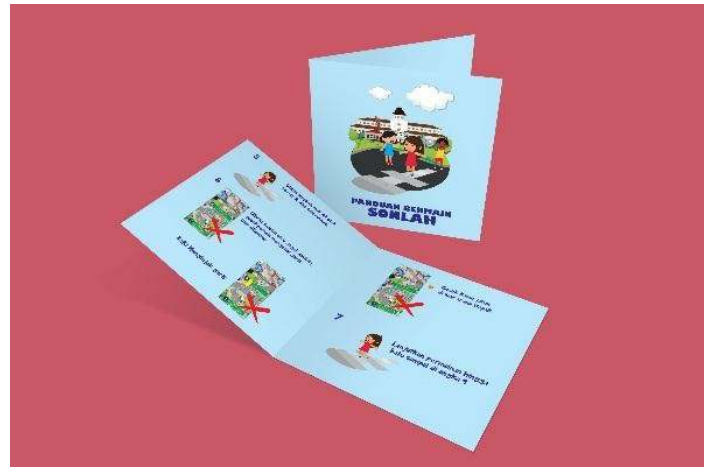

Gambar 4.59

Mockup Buku Panduan

Sumber: Olahan Penulis, 2017

\section{c. Stiker Bintang}

Stiker bintang warna warna terang dengan bahan kromo dengan ukuran $10 \times 10 \mathrm{~cm}$ digunakan sebagai pentanda wilayah yang dikuasai oleh pemain.
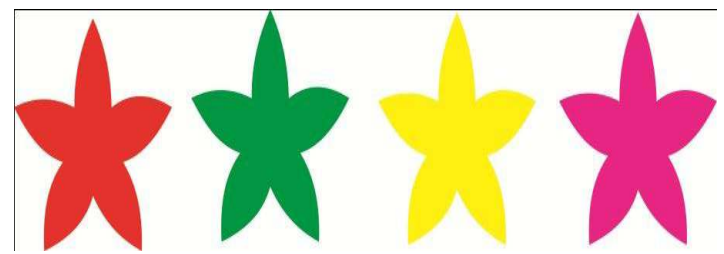

Gambar 4.60

Stiker Bintang

Sumber: Olahan Penulis, 2017

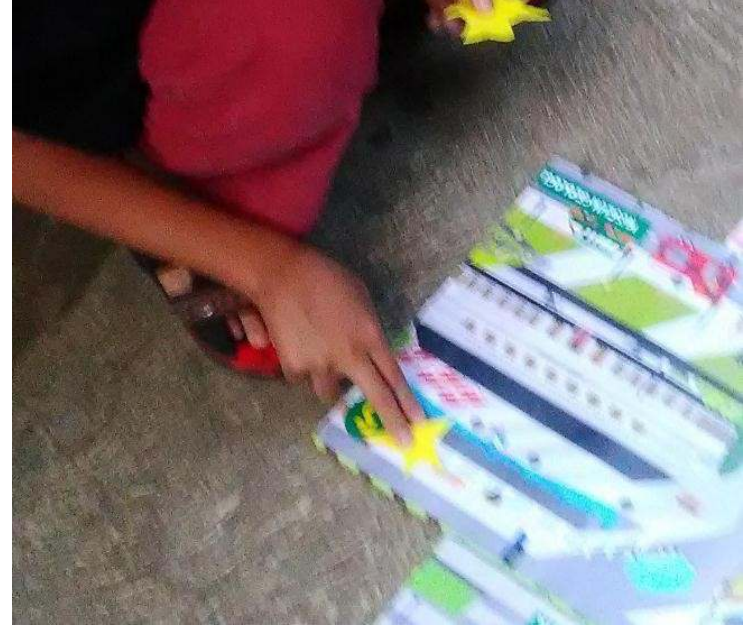

Gambar 4.61

Menempel Stiker

Sumber: Olahan Penulis, 2017

\section{d. Kemasan}

kemasan sebagai suatu wadah atau tempat dengan bentuk kotak dengan bahan duplek 300 g ukuran $60 \times 60 \mathrm{~cm}$ tinggi $8 \mathrm{~cm}$. Agar mudah di bawa, rapih dan melindungi.

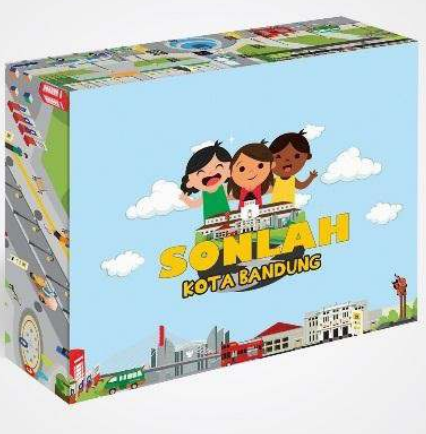

Gambar 4.62

Kemasan Box

Sumber: Olahan Penulis, 2017 


\section{e. Tas}

Penulis merancang dengan mengunakan Tas dengan ukuran $60 \times 60 \mathrm{~cm}$ dengan tebal $12 \mathrm{~cm}$ mengunakan bahan kanvas tebal dengan teknik printing kanvas dengan bahan printingflex agar warna keluar tahan lama. digunakan sebagai jijingan, agar mudah dibawa kemana - mana packgaging permainan sonlah tersebut.

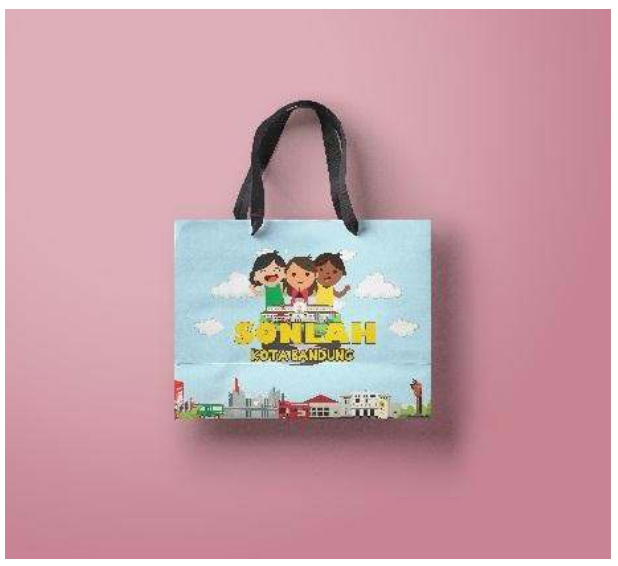

\section{Gambar 4.63}

Tas Box

Sumber: Olahan Penulis, 2017

\section{Kesimpulan}

Dalam merancang ulang suatu produk media ini diperlukan penelitian seperti survey dan riset langsung ke objek yang bersangkutan. Dengan metode penelitian seperti ini, baru dapat mengerti dan mengenal nilai-nilai serta kelebihan yang dapat ditonjolkan dari objek tersebut. Begitu juga sama dengan perancangan ulang media permainan sonlah. Diperlukan survey lapangan beserta wawancara dan ditambahi dengan kuisioner yang dibagikan pada anak-anak dan orang tua murid. Akhirnya setelah cukup mengenal masalah yang di hadapi, barulah proses kerja perancangan ulang media permainan dimulai.

Oleh sebab itu didapatkan solusi dengan dibuatlah perancangan ulang media dari permainan sonlah yang itu yang diharapkan agar masyarakat dapat mengenal Permainan Tradisional yang ada di indonesia, bahkan tertarik dan ingin mengenal lebih dalam sehingga Permainan sonlah dapat menjadi warisan kebudayaan di kemudian hari.

Sedangkan strategi yang diambil agar promosi permainan tradisional tersebut menarik bagi masyarakat yaitu dengan melakukan pendekatan desain kepada gaya yang sesuai dengan segmentasi namun tidak meninggalkan kesan tradisional yang ada pada suatu peninggalan sejarah, itu diharapkan dapat menarik perhatian segmentasi yang dituju yaitu anak-anak.

Berangkat dari nilai-nilai dan konsep yang mendukung dan semuanya itu di representasikan melalui bentuk media permaianan dengan desain yang lebih menarik dengan memasukan ikon sejarah kota sebagai media edukasi. Sehingga perancangan media permainan yang baru ini dapat mengubah pandangan

\subsection{Saran}

Saran dari perancangan ulang permainan sonlah untuk anak usia 6-12 tahun yaitu :

\section{Saran Akademis}

Dalam perancangan ulang media permainan sonlah ini tidak hanya agar

di daapat menarik minat orangtua dan anak anak agar tertarik pada permainan sonlah. Tapi memberikan acuan dan pedoman sebagai tolak ukur baik teori metodologi serta analisis dalam hal mengaplikasikan teori Desain Komunikasi Visual dalam perancangan.

\section{Saran Praktis}

Dengan ada perancangan ulang permainan sonlah di harapkan semakin banyak permainan tradisional dikembangkan dan dikenal oleh anakanak sekarang dan generasi yang akan datang.

\section{Daftar Pustaka}

Adhicipta R. Wirawan. 2008. Redesigning Joomla Template. Jakarta :PT elex Media Kompuntindo 
Andry,Koniyo.2007.TuntunanPraktisMemba ngunSistemAkuntasiDengan Visual Basic dan Microsoft SQL, Yogyakarat :Andi Offset

Anggraini, LiadanKiranaNathalia. 2014. DesainKomunikasiVisual:DasarDasarPandu anUntukPemula. Bandung: NuasaCendekia.

GunarsaSingihD,Novi. 2008. Psikologi Perkembangan Anak Dan Remaja Jakarta : Gunung mulia

Kusrianto

PengantarDesainIlmuKomunikasi Visual, Yogyakarta: Andi Offset

KusriniDkk. 2007. InformasiAkuntasidengan Visual Basic Microsof, Yogyakarta:

InsaniPressKusmiati,ArtiniRdkk.1999. TeoriDasarDesainKomunikasiVisual.Jakarta :Djambatan

Maguire Jack, 1990, Hopscoth, Hangman, Hot Potato \& Ha HaHa, Franc: The Philip Lief group. Inc

Musianto, Lukas S. 2002. Perbedaan Pendekatan Kuantitatif dengan Pendekatan Kualitatif dalam MetodePenelitian. Surabaya: Jurnal Manajemen Dan Kewirausahaan

Novi Mulyani,2016, Super AsyikPermainanTradisionalAnak Indonesia, Yogyakarta: Diva Press

Rifa Iva. 2012.Kolleksi Games Edukatif di DalamdanLuarSekolah, Yogyakarta :Flashbook
Sutopo, Ariesto Hadi. 2007. Desain Brosur dan Majalah dengan Adobe Indesign.. Jakarta: Elex Media Komputindo

Setiautami, Dria. 2011. Eksperimen Tipografi Dalam Visual Anak. Jakarta Barat: Humaniora

Yoyok RM, Siswandi.2006. PendidikanSeniBudaya,Yogyakarata :PT Ghalia Indonesia Printing.

Sumber Lain:

Kamus Besar Bahasa Indonesia , DepartemenPendidikanNasional, Jakarta 2008, hlm 968 Tuti Andriani, "Permainan Tradisional dalam Membentuk karakter anak" dalam jurnal sosial budaya vol. 9 nomor 1 januari-juli 2002, hlm 126.

M Zaini arif "the secret meaning of "hom pim pa" agustus 2011, cilandak jakarta https://www.youtube.com/watch? $\mathrm{v}=\mathrm{hRVrm} 3$ svaUk , 20 februari 2017 pukul 22.12

Jurnal :Johan Novtira Jamal dkkdalamjurnale-Proceeding of Art \& Design : Vol.2, No.1 April 2015 | hal.76 yang berjudulperancangan board game sang pemimpin

http://boardgame.id/5-alasan-board-game tidak-akan-ditinggalkan/, (diakses Pada 15 september 2017, pukul20.30 )

$\underline{\text { http://kbbi.web.id/rancang-2 ( Di aksesl }}$ 20maret 2017, pukul $17: 45$ ) 